САДЫМ Владимир Александрович кандидат культурологии, вице-президент Краснодарской региональной общественной организации «Федерация космонавтики Кубани», Краснодар, Российская Федерация Vladimir A. SADYM

Cand. Sci. (Museology, Conservation and Restoration of Historical and Cultural Objects), Vice-President, Krasnodar Regional Public Organization Kuban Cosmonautics Federation, Krasnodar, Russian Federation, sadymvlad@mail.ru ORCID: 0000-0002-2340-2585

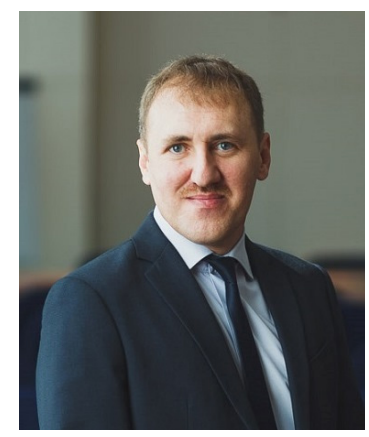

САДЫМ Каринэ Борисовна кандидат исторических наук, доцент кафедры философии, психологии и педагогики Кубанского государственного медицинского университета, Краснодар, Российская Федерация Karine B. SADYM Cand. Sci. (National History), Assoc. Prof., Kuban State Medical University, Krasnodar, Russian Federation, karinakor@mail.ru ORCID: 0000-0002-9892-4257

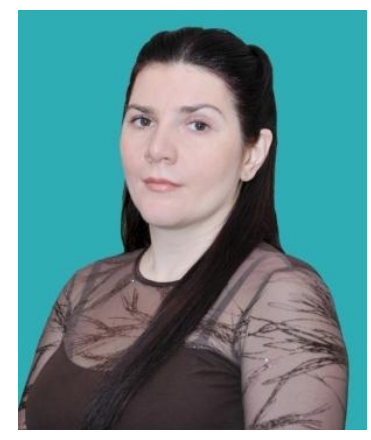

УДК [725.94:629.78]+061.75(470.62)

DOI: 10.36343/SB.2021.26.2.003

ГРНТИ 13.61.00

BAK 24.00.01

\section{Историко-культурное наследие космонавтики на Кубани: «места памяти» и коммеморативные практики}

\author{
Historical and Cultural Heritage \\ of Cosmonautics in Kuban: \\ "Places of Memory" \\ and Commemorative Practices
}

В статье проанализированы практики сохранения и трансляции историко-культурного наследия космонавтики в Краснодарском крае в период с 1960-х гг. до настоящего времени, определена роль данной деятельности в формировании культурной памяти. Основными источниками исследования послужили документы краевого общественного движения «Кубань и космонавтика», краснодарской региональной общественной организации «Федерация космонавтики Кубани», материалы музеев, периодики, интернет-сайтов, изданий, запечатлевших память об освоении космоса, памятники и памятные места, данные топонимики. Авторы рассматривают основные этапы, содержание и тенденции развития «космической» коммеморации, 
классифицируют «места памяти» и региональные коммеморативные практики, прослеживают преемственность советских и современных подходов. Сделаны выводы о многообразии форм сохранения памяти, об истории покорения космоса и его региональном «измерении», роли коммеморации в формировании региональной идентичности.

Ключевые слова: космонавтика, историко-культурное наследие, Краснодарский край, коммеморация, «места памяти», монументальные памятники, коммеморативные практики.

Введение. Актуальность темы исследования объясняется возрастающим вниманием отечественных и зарубежных исследователей к вопросам освоения историко-культурного наследия науки и техники, использования его потенциала в образовательных и воспитательных целях, в развитии регионального туризма.

Историко-культурное наследие космонавтики представляет собой совокупность технических и научных достижений в области освоения космического пространства, историю развития науки и ракетно-космической техники.

Начало космической эры было повсеместно воспринято как значимое, рубежное событие и стимулировало множественные инициативы в области сохранения наследия космонавтики, выявления и мемориализации связанных с ней объектов и памятных мест.

Отдельные аспекты темы уже нашли отражение в научных трудах. Так, исследовались биографии и деятельность уроженцев Кубани и живших в крае космонавтов, ученых, инженеров, внесших значительный вклад в освоение космоса [3] [8], сохранение памяти о них в музеях (в том числе школьных), в медиадискурсе [13] [19] [21] [22] [31] [33] [36], история общественного движения «Кубань и космонавтика» и краснодарской региональной общественной организации «Федерация космонавтики Кубани» (КРОО «Федерация космонавтики Кубани»), деятельность их руководителей, энтузиастов популяризации истории освоения космоса [5] [6] [25] [37].

В данной статье реконструируются «места памяти» космонавтики, выявляются практики сохранения и трансляции истории освоения космоса за последние 60 лет, а также определяется значение их деятельности в формировании культурной памяти. Исследование ограничено территорией Краснодарского края.

Источниковую базу составили разнообразные документы названных выше общественных организаций, фонды и экспозиции музеев, периодика, публицистические, научно-популярные и художественные издания, произведения изобразительного искусства, запечатлевшие память о региональных аспектах освоения космоса, мемориальные комплексы, памятники, мемориальные доски героям космоса, фото- и кинодокументы, тематические интернет-сайты.

Среди методов исследования выделим сравнительно-исторический, типологический и ретроспективный. Многолетняя работа одного из соавторов в КРОО «Федерация космонавтики Кубани», встречи с космонавтами, подготовка тематических конкурсов, церемоний открытия памятников и прочих актов коммеморации сделала возможным реализовать метод включенного наблюдения. Начальным этапом исследования стало создание баз данных объектов космического наследия в регионе и их классификация, выстраивание хронологии знаковых событий, способствовавших возникновению «мест памяти».

Важной представляется опора на труды теоретиков исторической коммеморации, особенно П. Нора, касающихся мест памяти, которые «рождаются и живут благодаря чувству, что спонтанной памяти нет, а значит - нужно создавать архивы, нужно отмечать годовщины, организовывать празднования, произносить надгробные речи, нотариально заверять акты, потому что такие операции не являются естественными» [23, с. 26].

Коммеморация понимается как «совокупность публичных коллективных практик, 
направленных на формирование ценностей и моделей поведения через ритуально оформленное удержание и воспроизведение (повторение) в актуальной культуре значимых для группы, символически выраженных представлений о прошлом» [35, с. 162].

Исследование «мест памяти» космонавтики на Кубани и коммеморативных практик позволит понять их значение в общественной и культурной жизни региона, в формировании местной идентичности, проследить преемственность советских и современных подходов к трансляции темы.

Анализ. Краснодарский край обладает богатым «космическим» наследием. С Кубанью связана жизнь и деятельность отечественных ученых в области ракетостроения: Н.Г.Чернышева (советский ученый-химик, доктор технических наук, один из разработчиков ракетного топлива, уроженец станицы Казанской Кавказского района), Ю. В. Кондратюка (А. И.Шаргея) (теоретик космонавтики, рассчитавший траекторию полета к Луне, независимо от К.Э. Циолковского вывел основные уравнения движения ракеты, работал в 1925-1926-х гг. на Кубани) и Г.Я.Бахчиванджи (Герой Советского Союза, летчикиспытатель первого советского самолета с реактивным двигателем, уроженец станицы Бриньковской Приморско-Ахтарского района). Их имена признаны мировым сообществом и присвоены кратерам на обратной стороне Луны. Уроженцем станицы Тихорецкой Кубанской области (ныне город Тихорецк) является Д.И. Козлов - дважды Герой Социалистического Труда, генеральный конструктор Государственного научнопроизводственного ракетно-космического центра «ЦСКБ-Прогресс», автор более 150 научных трудов и изобретений в области проектирования автоматических космических систем.

На Кубани родились и жили летчикикосмонавты: дважды Герои Советского Союза В. В. Горбатко, В. И. Севастьянов, Герой Советского Союза А.Н. Березовой, Герои Российской Федерации Г. И. Падалка, С. Е.Трещев, космонавт-испытатель системы «Энергия» с кораблем многоразового использования «Буран» А. В. Щукин.
Десятки космонавтов СССР и России прошли подготовку в Краснодарском высшем военном авиационном училище летчиков имени Героя Советского Союза А. К. Серова, Армавирском авиационном училище летчиков, Ейском авиационном училище.

В 1960 г. первая группа космонавтов СССР, в числе которых был Ю.А. Гагарин, проходила предполетную практику на Краснодарском аэродроме (ныне - Международный аэропорт Краснодар имени Екатерины II).

На базе Северо-Кавказского филиала Всесоюзного НИИ «АИУС-Агроресурсы» (позже - Южно-российский институт мониторинга земель и экосистем) прошли обучение дистанционному зондированию земли 38 космонавтов СССР и зарубежья [16].

В разные годы Кубань посещали советские и российские летчики-космонавты А.А.Леонов, В. М. Комаров, А.Г.Николаев. В. В. Терешкова, П. Р. Попович, В. Ф.Быковский, В. В. Лебедев, С.А. Волков, Б. В. Волынов, К. П. Феоктистов, В. А. Джанибеков, Г. М. Гречко, А. С. Иванченков, А. И. Лавейкин, В. П. Савиных, В. И. Токарев, С. В. Залетин и др. [13, с. 26-31].

Предприятия промышленного сектора и агропромышленного комплекса Краснодарского края продолжают работать на космическую отрасль: АО «Сатурн» осуществляет разработки в области физических и химических источников тока для космических аппаратов, ЗАО «Сад-Гигант» сотрудничает с Бирюлевским экспериментальным заводом по подготовке продуктов питания для космонавтов.

С началом эпохи практического освоения космического пространства космонавтика стала гордостью советских людей, оказав влияние на формирование их самосознания, ощущение сопричастности эпохе «покорителей космоса». Интерес к теме космоса возрастал в обществе с каждой новой победой советских космонавтов на околоземной орбите.

Активная коммеморация как процесс сохранения и увековечивания в общественном сознании памяти о значимых событиях в истории отечественной космонавтики 19601980-х гг. предполагала создание памятников, музеев, празднование годовщин, первых юбилеев пилотируемых полетов, проведение торжественных мероприятий. 
Опираясь на опыт имеющихся исследований, проведем классификацию «мест памяти» космонавтики на Кубани:

- мемориальные комплексы, памятники, бюсты, стелы, мозаичное панно/тематические мозаики, мемориальные доски;

- названия улиц, площадей, отдельных географических и инфраструктурных объектов, учреждений;

- краеведческие, художественные, специализированные «космические» музеи, в том числе школьные, их фонды, экспозиции, выставки космической тематики;

- планетарии и обсерватории;

- общественные организации, их архивы, печатные издания;

- природные объекты - мемориальные деревья, аллеи и т.д.

Особым культуросозидающим потенциалом и исторической ценностью, на наш взгляд, обладают монументальные объекты. Первым из них стал памятник Ю.А. Гагарину (1963) в Анапе на территории ныне не суще-

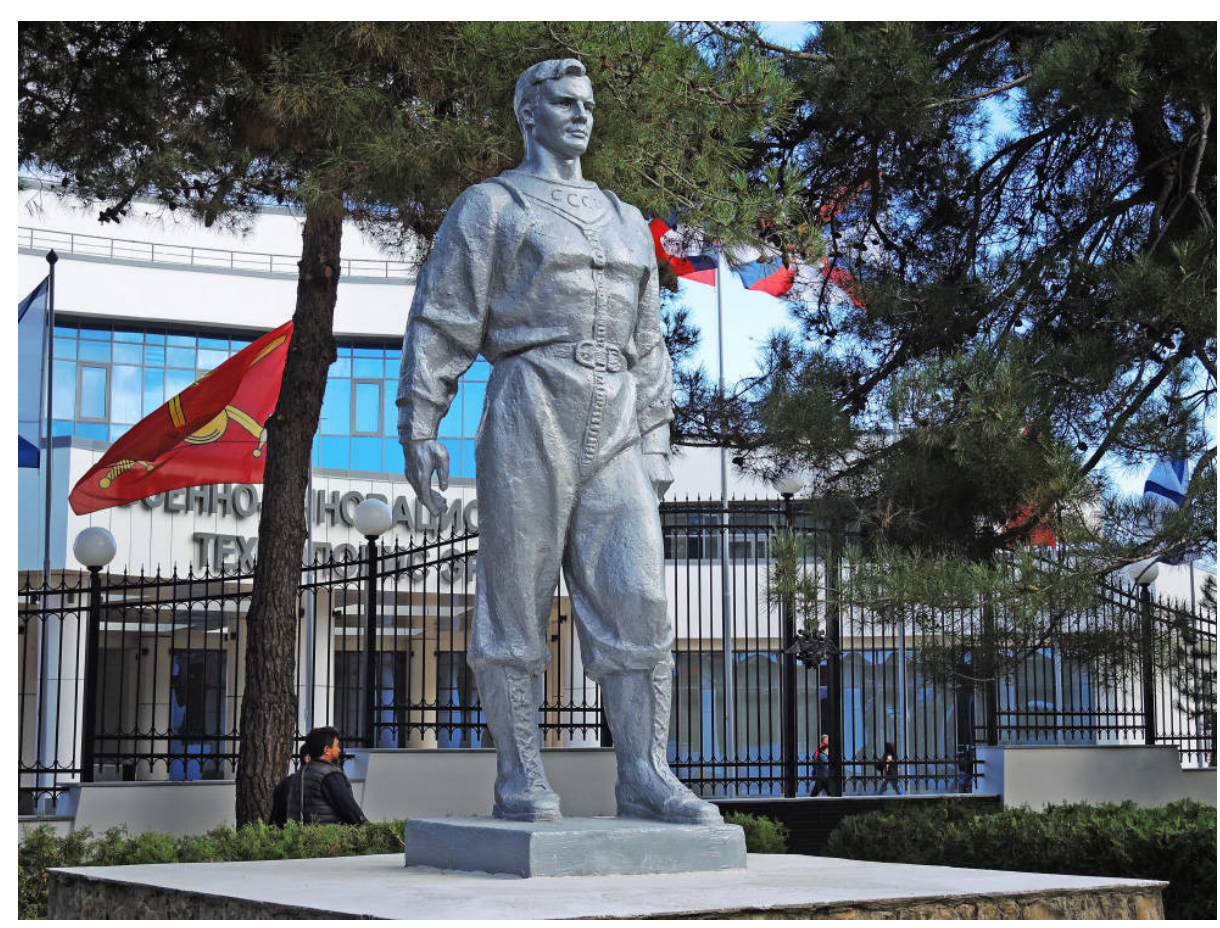

Рис. 1. Памятник Ю. А. Гагарину в Анапе

Fig. 1. Monument to Yu. A. Gagarin in Anapa ${ }^{1}$ ствующего пионерского лагеря имени Ю. А. Гагарина (рис. 1). В настоящее время памятник находится рядом с военно-инновационным технополисом «Эра».

На территории Краснодарского края имеется несколько мемориальных комплексов космонавтики, включающих в себя площади, памятники. Монументальное пространство, как правило, дополняется музейным учреждением, названиями улиц и школ.

Первый по времени создания - комплекс Ю.В.Кондратюка в станице Октябрьской Крыловского района (1973), в который вошли музейная комната на Крыловском элеваторе, где работал ученый, бюст, музей средней школы № 6 и улица имени Ю. В. Кондратюка. Данный комплекс был открыт благодаря усилиям общественного движения «Кубань и космонавтика» и личной поддержке академика В. П. Глушко [25, с. 36-38].

В начале 1980-х гг. сформировался мемориальный комплекс Г. Я. Бахчиванджи в станице Бриньковской Приморско-Ахтарского района в составе скульптуры летчика-испытателя (рис. 2), макета самолетов БИ-1, МиГ-21, улицы, школы имени Г.Я.Бахчиванджи, а также бюста, установленного еще в 1967 г.

В конце 1990-х гг. при поддержке общественного движения «Кубань и космонавтика» появился мемориальный комплекс «первого химика космонавтики» Н.Г. Чернышева в станице Казанской Кавказского района (1998): бюст, школьный музей, школа, улица и дом, где родился ученый. Дом в станице Казанской (ул. Чернышева, 72) отнесен к памят-

${ }^{1}$ Источник: Речной форум. URL: https://riverforum.net/ showthread.php?t=4710\&page $=28 \& \mathrm{p}=335904$

Source: Rechnoy Forum [River Forum]. [Online] Available from: https://riverforum.net/showthread. php?t=4710\&page $=28 \& \mathrm{p}=335904$

никам истории регионального значения, однако в настоящее время практически разрушен.

В процессе исследования на Кубани за период с 1960 по 2020 гг. выявлены порядка 
20 бюстов летчиковкосмонавтов, ученых и первопроходцев отечественной космонавтики. К их числу относятся упомянутые ранее бюсты Г. Я. Бахчи ванджи в станице Бриньковской и Ю.В.Кондратюка в станице Октябрьской. 12 апреля 1975 г. в Сочи на улице имени Ю.А.Гагарина открыт мраморный бюст первого космонавта. Элементом мемориального ландшафта, помимо то пон и мического маркера и бюста, стал гималайский кедр, высаженный космо-

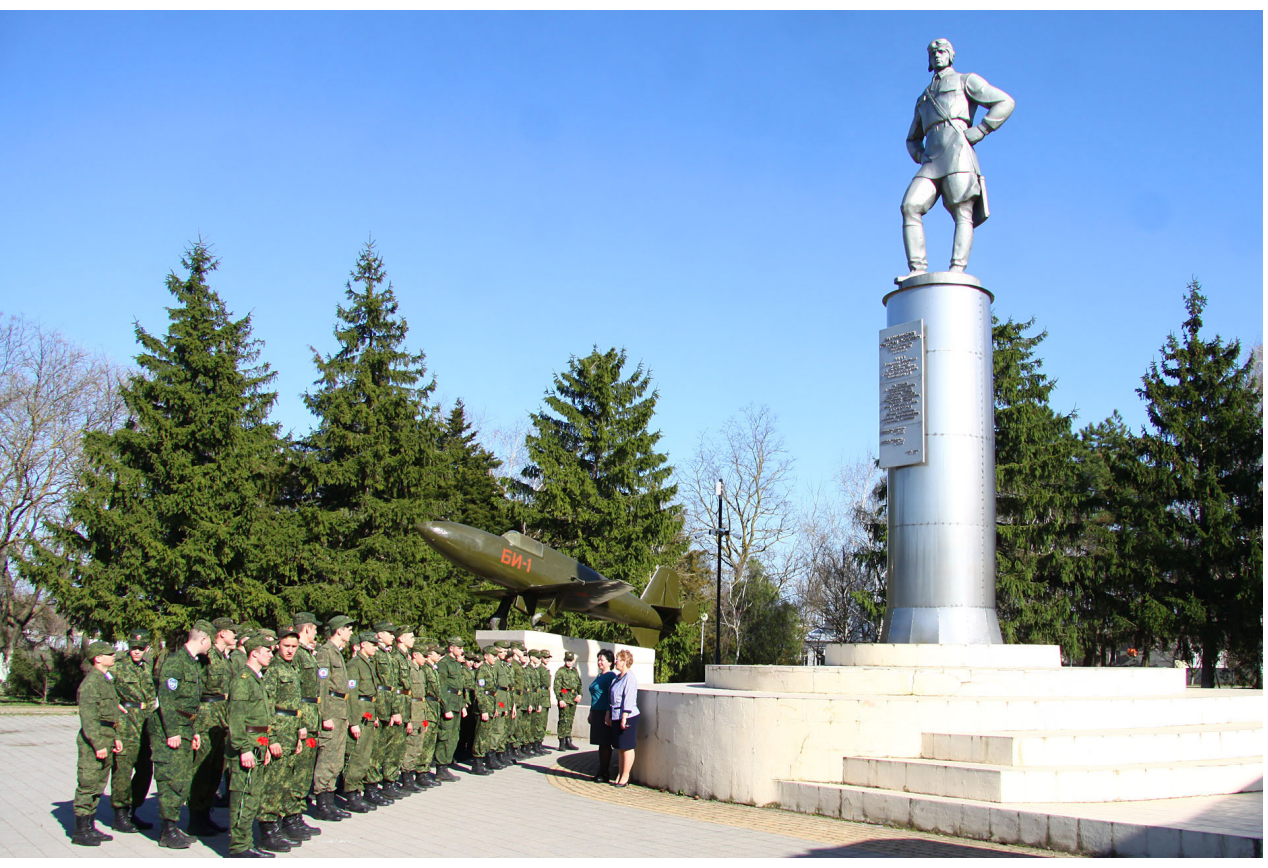

Рис. 2. Мемориальный комплекс Г. Я. Бахчиванджи в станище Бриньковской Приморско-Ахтарского района Краснодарского края, 2020 г. Фото Т. А. Бутко Fig. 2. G. Ya. Bakhchivandzhi memorial complex in Stanisa Brinkovskaya, Primorsko-Akhtarsky District, Krasnodar Krai, 2020. Photo by T. A. Butko навтом в мае 1961 г.

во время пребывания в городе-курорте на реабилитации после полета. В 1980-е гг. на Кубани появились бюсты Д.И.Козлова (1981) и В. В. Горбатко (1985). Автором большинства памятников является известный скульптор В.А.Жданов, лично встречавшийся с кубанскими космонавтами. Отдельные произведения скульптуры экспонируются в музеях, например, бюст В.В. Горбатко работы В. А.Жданова с 1980-х гг. выставлен в картинной галерее станицы Привольной Каневского района.

Среди памятников космонавтам последних десятилетий - бюсты Ю.А. Гагарина в Анапе (2011), Краснодаре $(2011,2014)$, Ейске (2011), поселке Архипо-Осиповка (2012), Новороссийске (2015), Хадыженске (2016), поселке Парковый Тихорецкого района (2019); бюсты В. И. Севастьянова в Сочи $(2005,2019)$; бюсты В.В. Горбатко в Новокубанске (2003), Армавире (2018); бюст В. М. Комарова в Краснодаре (2021).

Пример современного монументального объекта - памятник «Планета Земля» в Армавире в виде гранитного шара (2019). К 60-летию полета Ю.А. Гагарина в Новороссийске создана стела «Утро космической эры» возле планетария имени Ю.А. Гагарина рядом с макетом ракетоносителя «Восток».

Произведения монументальной живописи на территории Краснодарского края представлены мозаичным панно на здании школы № 5 станицы Бриньковской (1967), мозаикой «Пионерия и космос» (1964) на фасаде здания детского лагеря «Звездный» Всероссийского детского центра «Орленок», где авторы (художники Ю. Королев и В.Балуев) изобразили мечту многих советских школьников о покорении звездных высот (рис. 3). Заслуженный художник России А.Н. Скрипников является автором нескольких «космических» панно в Сочи - на здании кинотеатра «Спутник» (ныне утраченного) и мозаичной композиции покорителям космоса на стенах открытой круговой веранды сочинского цирка (1971).

Среди «мест памяти» можно выделить мемориальные доски на улице имени Ю. А.Гагарина в Краснодаре (1968); «Первопроходцам космоса» (2001) на административном здании краснодарского аэропорта (рис. 4), где первая шестерка космонавтов СССР проходила предполетную практику; Н. Г. Чернышеву на здании школы № 20 в станице Казанской; многочисленные памятные доски на зданиях 


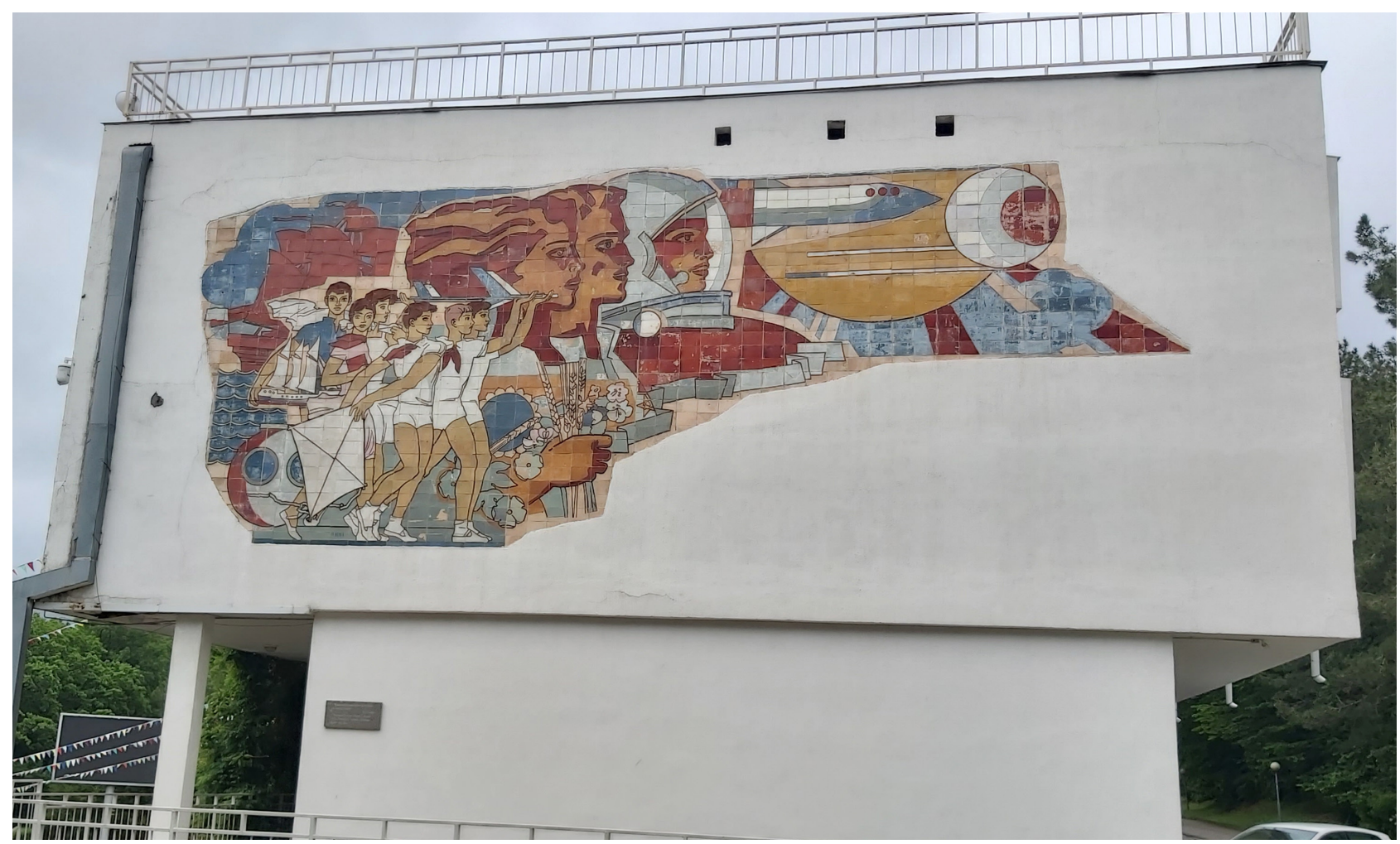

Рис. 3. Мозаичное панно «Пионерия и космос»

на здании лагеря «Звездный» в ВДЦ «Орленок», 2021 г. Фото В. А. Садыма

Fig. 3. Mosaic panel Pioneer and Space on the building of the camp Zvezdny in the Orlenok All-Russian Children Center, 2021. Photo by V. A. Sadym

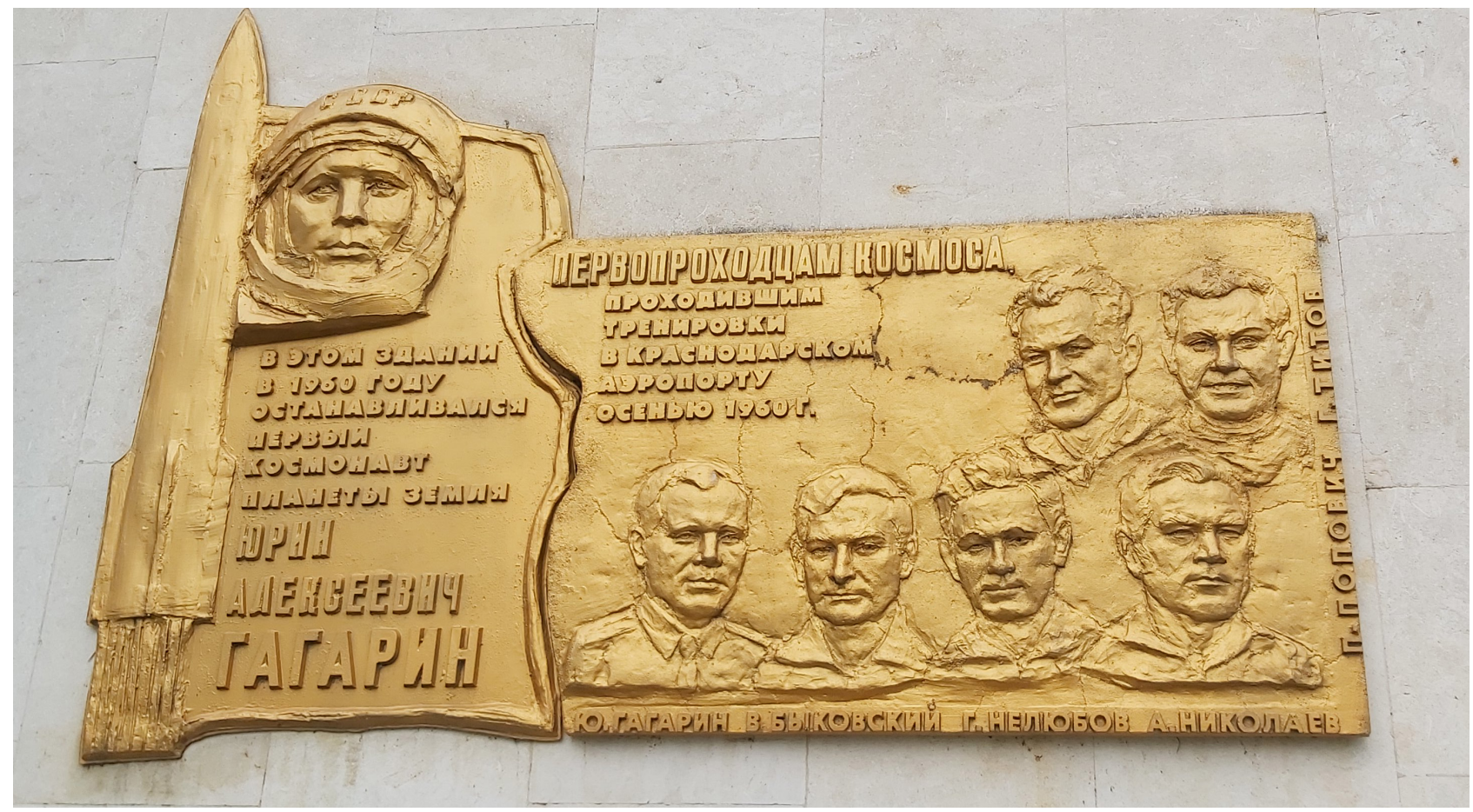

Рис. 4. Мемориальная доска «Первопроходцам космоса» на административном здании Международного аэропорта Краснодар имени Екатерины II, 2021 г. Фото В. А. Садыма Fig. 4. Commemorative plaque To Space Trailblazers on the administrative building of the Catherine II Krasnodar International Airport. 2021. Photo by V. A. Sadym 
средних общеобразовательных учреждений Краснодарского края, носящих имя Ю.А.Гагарина и кубанских космонавтов. Установка мемориальных досок в честь увековечения памяти о выдающихся исторических деятелях и значимых исторических событиях была и остается самой востребованной формой коммеморации в нашей стране [1].

Имена первопроходцев увековечены в названиях улиц, площадей, бульваров. Согласно исследованиям интернет-проекта «Тинькофф Журнал», «чаще всего в России они связаны с именем Юрия Гагарина: таких почти 6,5 тысяч. На втором месте по популярности - космонавт Владимир Комаров: его именем названо 1,4 тысячи улиц, переулков и т.п. Самый «космический» регион - Краснодарский край: 727 таких названий. На втором месте - Московская область: 535. На третьем - Татарстан: 530» [14].

В списке «космических» названий Краснодара - улицы имени Ю.А.Гагарина, К.Э. Циолковского, .П.Королева, Г.Я.Бахчиванджи, В.М. Комарова, Звездная, Космонавтов, Лунный переулок, переулок Звездный, бульвар Гагаринский. В Краснодарском крае такие топонимические объекты есть во всех городах и практически в каждом населенном пункте.

Мемориализация «космических» героев Кубани в топонимике наиболее характерна для населенных пунктов, где родились или жили деятели космонавтики: улицы имени В. В. Горбатко - в поселках Восход и Прогресс Новокубанского района, Армавире; имени Г.Я.Бахчиванджи - в станице Бриньковской, Приморко-Ахтарске; имени Ю.В.Кондратюка - в станице Октябрьской; имени Н. Г. Чернышева - в станице Казанской, Краснодаре; имени В. И. Севастьянова - в Сочи.

«Космические» наименования носили и носят досуговые и санаторно-курортные учреждения Кубани: молодежный туристический лагерь «Спутник» (1960) в Сочи (ныне отель Alean Family resort \& Spa Спутник), гостем которого в 1961 г. был Ю.А. Гагарин; пионерский лагерь «Спутник» (1961) в Анапе (ныне - санаторно-оздоровительный комплекс «Спутник»); детский оздоровительный комплекс «Спутник» в селе Кабардинка; кино- театр «Спутник» в Сочи (1959), оформленный мозаичным панно с портретом Ю.А. Гагарина (утраченный в настоящее время); кинотеатр «Космос» в Краснодаре (1967) (ныне «Болгария»); кинотеатр «Космос» в станице Каневской (1964).

Имена героев космоса присваиваются средним образовательным учреждениям. Нами выявлены порядка 20 таких учреждений, носящих имена деятелей космонавтики, главным образом Ю. А. Гагарина (школа № 20 поселок Красный Октябрь Темрюкского района, школа № 8 Туапсе, школа № 2 села Успенское, школа № 2 Курганинска, школа № 6 Кропоткина, школа № 2 села Шабановское Северского района, гимназия № 14 Ейска, гимназия в станице Каневской). Имя первого космонавта присвоено школе № 7 Хадыженска Апшеронского района 14 апреля 1961 г., то есть через два дня после полета Ю.А. Гагарина. Имя А. Н. Березового присвоено гимназии № 18 Краснодара, школам № 53 поселка Найдорф Динского района и № 18 села Николаевское Гулькевичского района. В Сочи лицей № 95 носит имя К. Э. Циолковского, в Краснодаре гимназия № $72-$ имя академика В. П. Глушко.

Пример «космического» наименования инфраструктурного объекта на территории Краснодарского края - международный аэропорт Сочи имени В. И. Севастьянова.

В Краснодарском крае имеются специализированные музеи космонавтики: музей космонавтики в селе Архипо-Осиповка, мемориальный музей Ю.В.Кондратюка в станице Октябрьской, музей авиации и космонавтики Краснодарского высшего военного училища летчиков им. А.К. Серова в Краснодаре, дом авиации и космонавтики во Всероссийском детском центре «Орленок», а также музей космонавтики станицы Каневской, на базе которого в 2021 г. создано Каневское отделение общероссийской общественной организации «Ассоциация музеев космонавтики».

Постоянные экспозиции космической тематики представлены в музеях истории города-курорта Сочи, Анапском краеведческом музее, музее станицы Бриньковской имени Г.Я.Бахчиванджи, Тихорецком историкокраеведческом музее, музее истории боевой славы Армавирского летного училища. 
Долгие годы в Краснодарском историкоархеологическом музее-заповеднике имени Е. Д. Фелицына (КГИАМЗ) действовала постоянная выставка «Кубань и космонавтика», созданная научным сотрудником М.Р.Струговой в сотрудничестве с профессором Т. И. Агаповой и ее преемником - президентом КРОО «Федерация космонавтики Кубани» Э. М. Траховым.

Вообще совместная работа КГИАМЗ и общественного движения «Кубань и космонавтика» по формированию фондов и созданию «космических» выставок началась в 1970-е гг. Серьезным событием стала выставка «Человек и космос» (1990). Созданная к 40-летию полета Ю. А. Гагарина выставка «Кубань и космонавтика» была преобразована в «передвижную» и до 2005 г. экспонировалась в музеях Краснодара, Темрюка, Горячего Ключа, Лабинска, станиц Отрадная, Павловская и др. В 2011 г. Э. М.Трахов подарил музею более 100 экспонатов, среди них глобус Луны; модели (многоразового самолета «Буран», пер- вого отечественного жидкостного ракетного двигателя ОРМ-1, РД-119); памятные медали С. П. Королева, В. П. Глушко, Ю.А. Гагарина, Н. Армстронга, выпущенные всероссийской общественной организацией «Ассоциация музеев космонавтики»; знамя «Краснодарский региональный центр ВНИИ «АИУС-Агроресурсы»; фотографии и документы.

Большой интерес представляют школьные музеи космонавтики и экспозиции космической тематики в школьных музеях, рассмотренные нами ранее [33].

К «местам памяти» космонавтики относятся планетарии и обсерватории, многие из которых занимаются собирательской деятельностью и формируют собственные экспозиции по истории космонавтики. Например, планетарий имени Ю.А. Гагарина в Новороссийске, астрофизическая оптическая обсерватория Кубанского государственного университета, частная обсерватория «Солнечный ветер» в поселке Мезмай Апшеронского района,

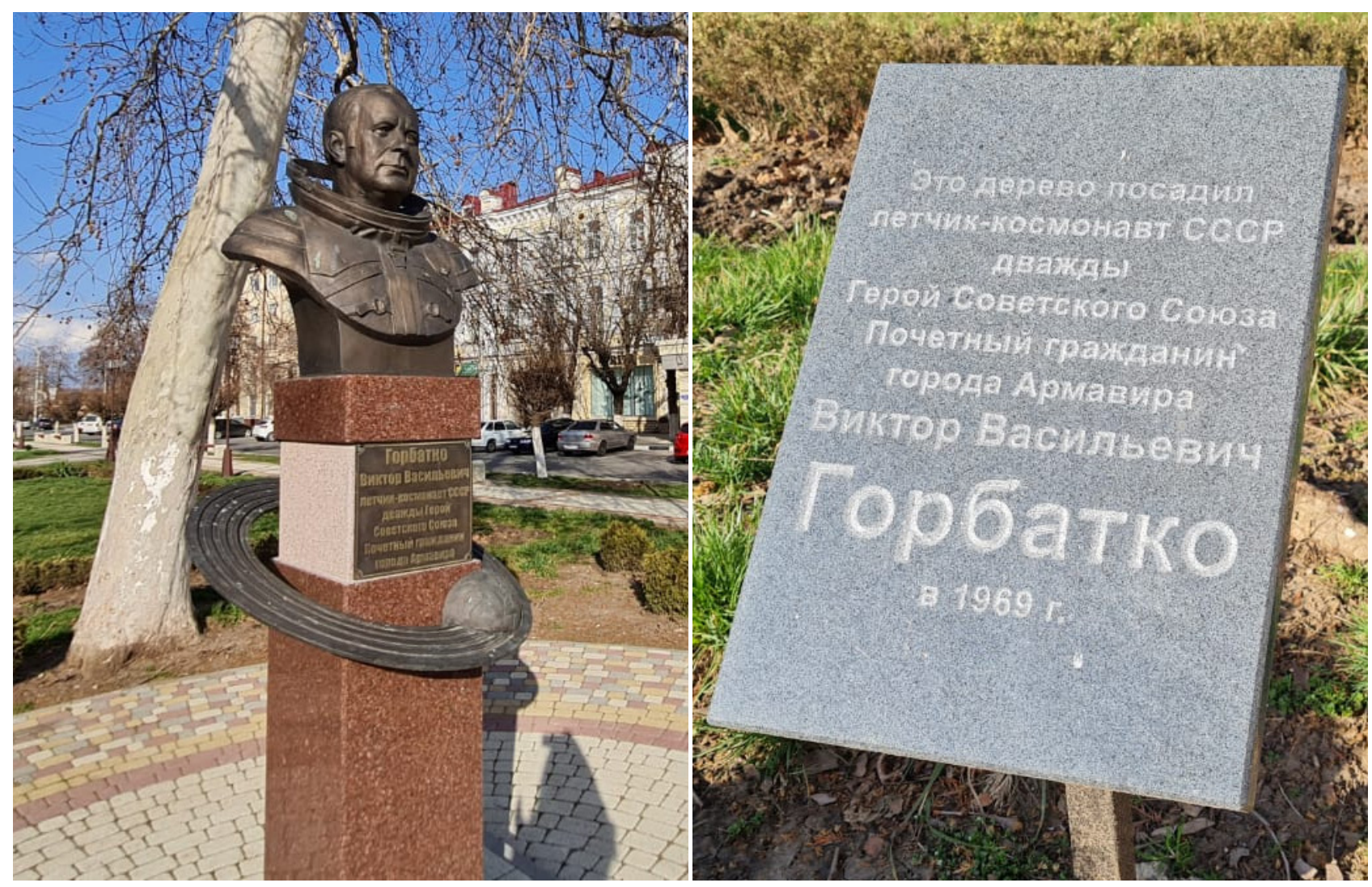

Рис. 5. Бюст дважды Героя Советского Союза летчика-космонавта В. В. Горбатко и высаженный им в 1969 г. платан в Армавире, 2021 г. Фото: Л. Г. Юдаевой Fig. 5. Bust of Twice Hero of the Soviet Union pilot-cosmonaut V.V. Gorbatko and the plane tree he planted in Armavir in 1969, 2021. Photo by L. G. Yudaeva 
детская обсерватория в ВДЦ «Орленок», планетарии в станице Ярославской Мостовского района и парке отдыха «Солнечный остров» в Краснодаре.

Роль «мест памяти» выполняют «космические» общественные организации, их архивы, печатные издания и практики по увековечиванию имен и событий в истории космонавтики. Деятельность краевого общественного движения «Кубань и космонавтика» и КРОО «Федерация космонавтики Кубани» ранее уже становилась предметом нашего исследования [32].

В качестве «мест памяти» выступают природные объекты - мемориальные деревья и аллеи, высаженные космонавтами или посвященные им. Гималайский кедр, посаженный в Сочи Ю. А. Гагариным (1961), и «Дерево дружбы», на котором делали прививки Ю. А. Гагарин, В.В. Терешкова и В. М. Комаров (1964), являются объектами туристического показа. Платан и березы посажены В.В. Горбатко в Армавире (1969) (рис. 5), Гулькевичах и поселке Венцы Гулькевичского района (1984), в станице Передовой (1986) (рис. 6), дерево ореха - А. Н. Березовым и С.Е.Трещевым на территории Кубанского государственного политехнического университета (2011). Аллея елей заложена кубанскими космонавтами А.Н.Березовым, В.В. Горбатко и В.И.Севастьяновым в Краснодаре (1983). Деревья на Аллее космонавтов в Анапе посадили В.В.Горбатко (1977), позже - А.Г.Николаев, А.А. Леонов, Г.Т. Береговой. Звездная аллея в станице Бриньковской с деревьями, посаженными космонавтами В.В.Аксеновым,
В. И.Рождественским, В.В.Горбатко, А.Н.Березовым, формировалась в 1980-2000-е гг. Каштановую аллею высадили студенты Краснодарского политехнического института к 10-летию полета Ю.А. Гагарина. В разные годы космонавтами и членами КРОО «Федерация космонавтики Кубани» посажены деревья у планетария Новороссийска. Природные памятные объекты снабжены информационными табличками с указанием дат высадки, событий и имен деятелей космонавтики, которым они посвящены.

Некоторые памятные места космонавтики безвозвратно утрачены или лишены своих прежних функций. Среди них здание кафе «Спутник» (конец 1970-х гг.) в Краснодаре в виде летающей тарелки, созданное по проекту финского архитектора М.Сууронена, но утратившее свое назначение в на-

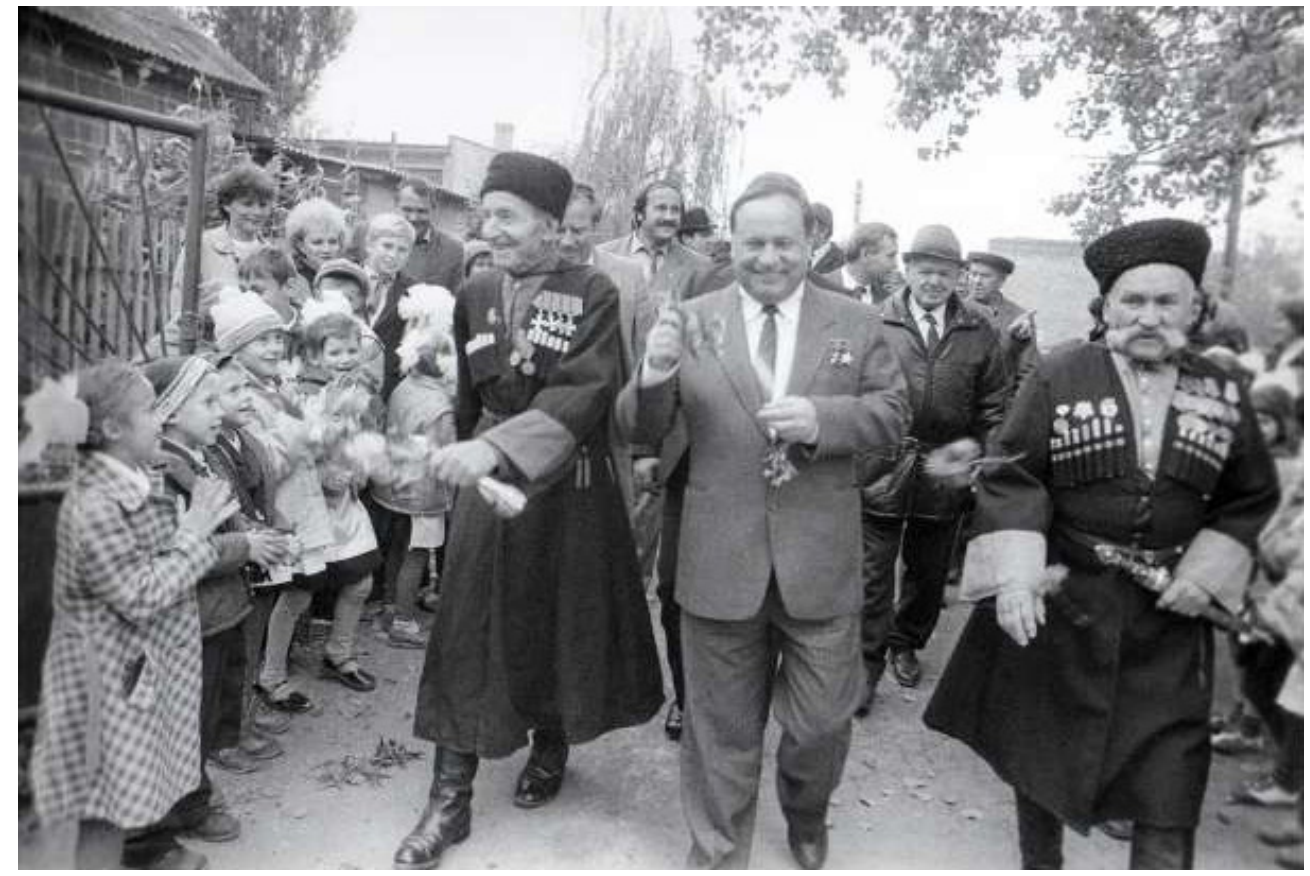

Рис. 6. Визит дважды Героя Советского Союза летчика-космонавта B. В. Горбатко в станице Передовая Отрадненского района Краснодарского края Fig. 6. Visit of Twice Hero of the Soviet Union pilot-cosmonaut V. V. Gorbatko to Stanitsa Peredovaya, Otradnensky District. Krasnodar Krai ${ }^{2}$
${ }^{2}$ Источник: Сельская жизнь. Общественно-политическая газета Отрадненского района Краснодарского края. URL: http://www.v-life.ru/index.php?area=news\&id=7278

Source: Sel'skaya zhizn'. Obshchestvenno-politicheskaya gazeta Otradnenskogo rayona Krasnodarskogo kraya [Rural Life. Social and Political Newspaper of the Otradnensky District of Krasnodar Krai]. [Online] Available from: http:// www.v-life.ru/index.php?area=news\&id=7278 
стоящее время. В конце 1990-х гг. прекратила существование мемориальная комната-музей на Крыловском элеваторе, где в 1925-1926 гг. работал Ю.В.Кондратюк. Ее экспонаты располагаются в музее космонавтики ученого во дворце культуры станицы Октябрьской. В 1990-е гг. утрачен музей космонавтики и аллея космонавтики на территории пионерского лагеря им. Ю. А. Гагарина в Анапе. Утраченным произведением монументальной живописи вследствие сноса здания в 2007 г. является мозаика «Покорение космоса» с портретом Ю.А.Гагарина на кинотеатре «Спутник» в Сочи. Практически разрушены дом в станице Казанской, в котором родился Н.Г.Чернышев, и памятник первому искусственному спутнику Земли в станице Некрасовская (рис. 7).

Среди естественно утраченных памятныхобъектов- магнолия, посаженная Ю. А. Гагариным в парке «Ривьера» в Сочи, на ее месте высажено дерево памяти космонавта; рябина, посаженная В.В.Горбатко в поселке Венцы Гулькевичского района в 1980-е гг.

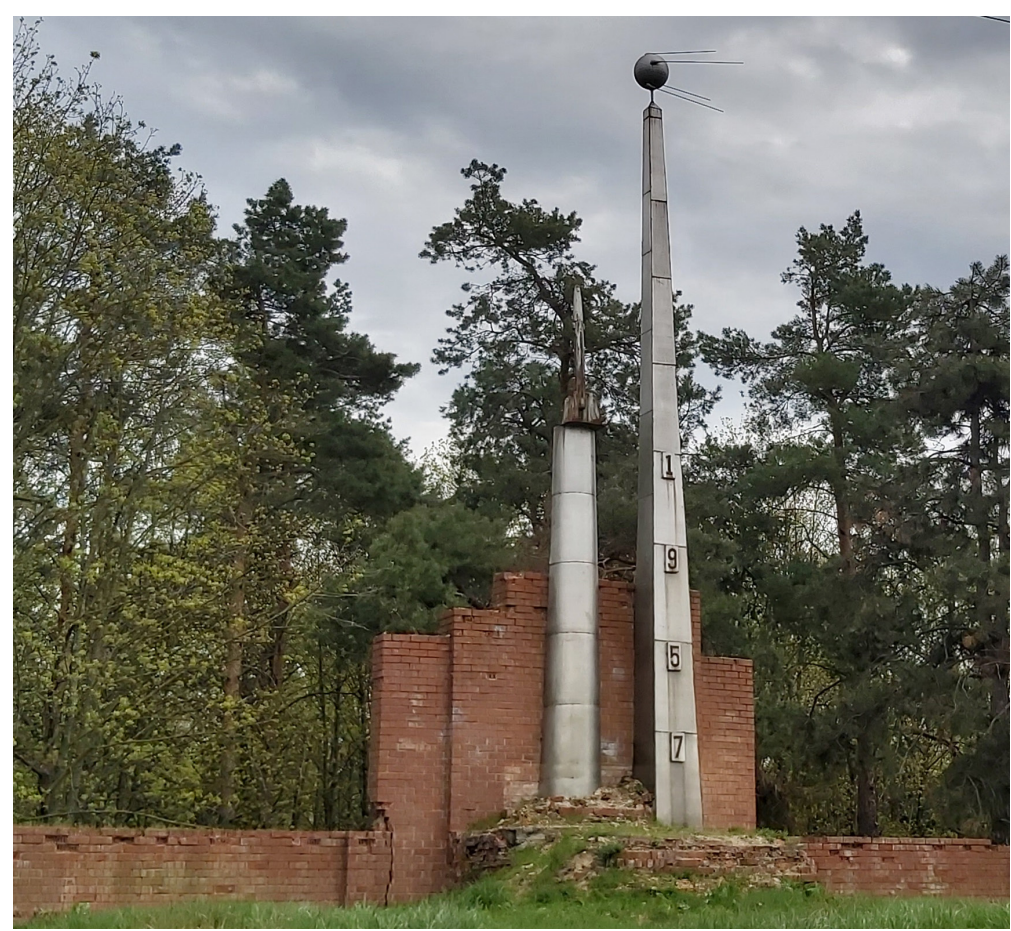

Рис. 7. Стела «Покорителям космоса», посвященная первому искусственному спутнику Земли в ст. Некрасовская Усть-Лабинского района Краснодарского края, 2021 г. Фото В. А. Садыма

Fig. 7. Stele Conquerors of Space dedicated to the first artificial Earth satellite in Stanitsa Nekrasovskaya, Ust-Labinsk District, Krasnodar Krai, 2021. Photo by V. A. Sadym
Память об истории освоения космоса поддерживается посредством разнообразных практик. Это торжества, посвященные памятным датам в истории освоении космоса и отдельным космонавтам; встречи с космонавтами; тематические художественные выставки и конкурсы; публичное исполнение поэтических и музыкальных произведений о космосе; презентации музейных экспозиций и тематические экскурсии; демонстрация документальных фильмов, радио- и телевизионных передач, интернет-проектов; издание популярной печатной продукции; проведение научно-практических конференций различного уровня, детских конкурсов космической тематики, спортивных соревнований на приз космонавтов.

Особая роль в акте передачи коллективной памяти о прошлом принадлежит встречам космонавтов с трудовыми коллективами, учащимися, жителями Краснодарского края, открытие музеев и памятников. Часто эти встречи совпадали с празднованием памятных дат в истории космонавтики.

Массовые мероприятия сопровождали открытие новых памятных объектов. 4 октября 1973 г. при участии общественности края открыт мемориальный комплекс Ю.В.Кондратюка в станице Октябрьской. Космонавты В. И. Севастьянов, А.Г.Николаев, В.А. Ляхов, В.В.Рюмин стали посетителями новой выставки «Космонавты в Сочи» в музее истории города-курорта Сочи (1979) [20]. Значимым для края было открытие мемориального комплекса Г.Я.Бахчиванджи в станице Бриньковской с участием космонавта В.И.Рождественского, летчика-испытателя С. А. Микояна (1984). В период празднования 90-летия Н.Г.Чернышева открыта мемориальная доска, заложен камень на месте будущего бюста ученому в станице Казанской Кавказского района (1996). Большим событием стал визит В.В.Горбатко и открытие бюста Ю.А. Гагарина в КВВАУЛ (2014) [24]. 
Примером традиционной коммеморации на Кубани является проводимый с 1971 г. ежегодный легкоатлетический кросс на призы В. В. Горбатко; с 2017 г. посвящен памяти космонавта.

К 30-летию полета Ю.А.Гагарина и 20-летию общественного движения «Кубань и космонавтика» Краснодарский краевой комитет космонавтики при содействии краевого комитета ВЛКСМ, краевого совета ВООПИК, управления народного образования Краснодарского края, Краснодарского государственного института культуры, СКФ-ВНИЦ «АИУС-Агроресурсы» провел «дни Ю.А.Гагарина». Программа предусматривала серию радио- и телепередач «Кубань и космонавтика», торжественные вечера, выставки в школах и ПТУ, спортивные соревнования в Краснодаре, Сочи, Крыловском, Усть-Лабинском, Приморско-Ахтарском, Гулькевичском, Туапсинском районах, пионерском лагере «Оpленок», встречи трудовых коллективов с кубанскими композиторами В.Д. Пономаревым, Ю.А. Симакиным, А.И. Поповым, проведение малых «гагаринских чтений», краевого смо-

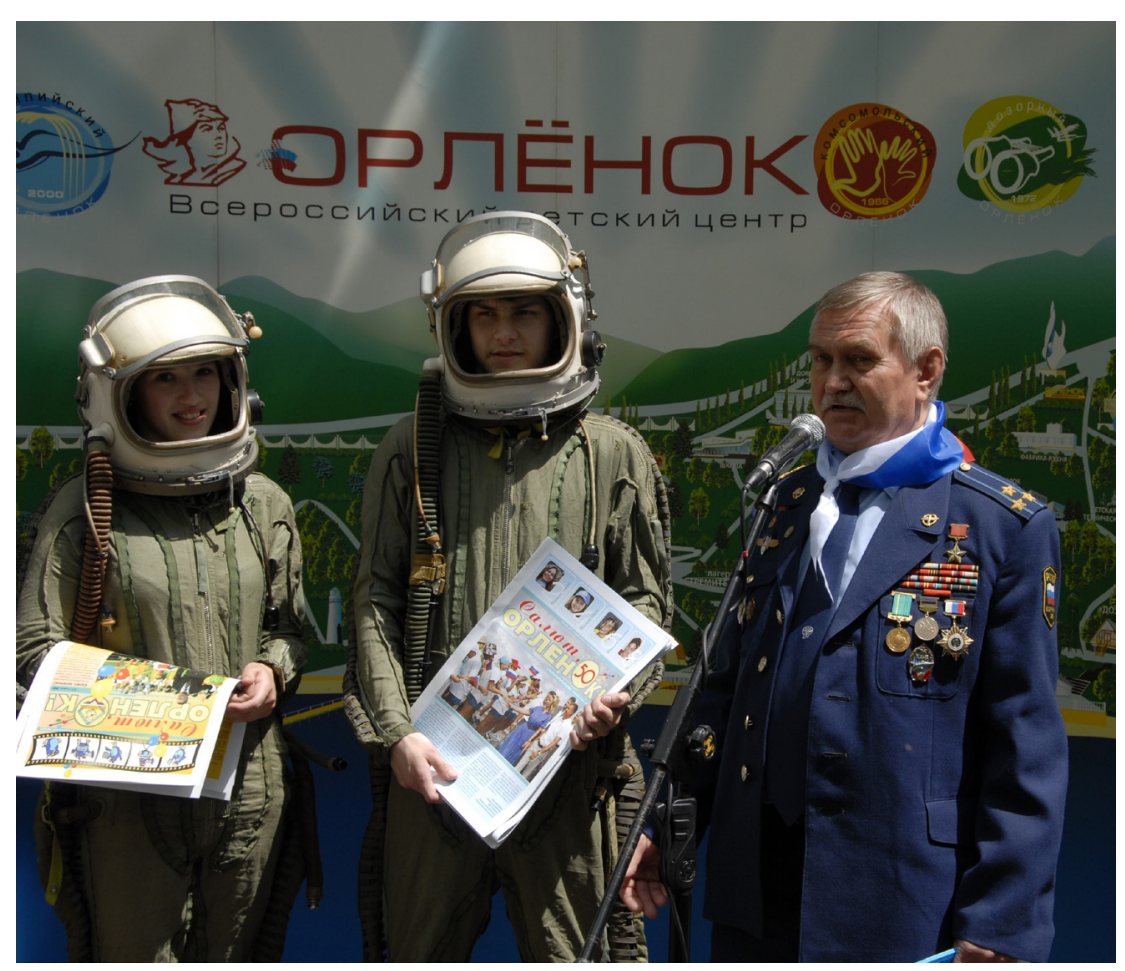

Рис. 8. Герой Советского Союза летчик-космонавт А. Н. Березовой с участниками «КоСМИческого фестиваля» в Краснодаре, 2011 г. Фото В. А. Садыма

Fig. 8. Hero of the Soviet Union pilot-cosmonaut A. N. Berezovoy with the participants of the Cosmic Festival in Krasnodar, 2011. Photo by V. A. Sadym тра памятников авиации и космонавтики, кинофестиваля [28].

После некоторого перерыва после распада СССР в связи с подготовкой к 40-летию начала космической эры возобновляется проведение молодежных научно-практических конференций, издание журналов, брошюр в крае.

Интересен опыт разработки автобусной экскурсии «Кубань и космонавтика» в 1984 г. по Краснодару, воссозданной в 2002 г. по инициативе общественного движения «Кубань и космонавтика» и турфирмы «Кубаньтурист» для краснодарских школьников. Маршрут пролегал через музей КВВАУЛ, Площадь Героев в сквере Г. К. Жукова, «Аллею космонавтов», дом А. Н. Березового в поселке Энем Республики Адыгея.

Широкий общественный резонанс вызвали юбилейные мероприятия, проводимые при поддержке краевых органов власти [26]. Так, к 45-летию полета Ю. А. Гагарина и 35-летию деятельности общественного движения «Кубань и космонавтика» наряду с традиционными мероприятиями патриотической направленности для детей и юношества в крае реализованы издательские инициативы [3] [22], открыты новые экспозиции в школах.

Тематические мероприятия 2011 г. также проводились на государственном уровне в рамках объявленного Года российской космонавтики: «КоСМИческий фестиваль» краевых средств массовой информации в Краснодаре (рис. 8), выставки «Космические маршруты кубанцев» и «50 лет в космосе: летопись покорения» в КГИАМЗ (рис. 9), открытие бюста Ю.А. Гагарина в Анапе; открытые показы документальных фильмов и лекции для жителей города, запуск стилизованного «космического» трамвая в Краснодаре, чествование ветеранов движения «Кубань и космонавтика» в ВДЦ «Орленок». Выставка современных кубанских 
художников, где были представлены работы космической тематики, состоялась в Краснодарском краевом художественном музее имени Ф. А. Коваленко (ККХМ). Большой резонанс вызвал фестиваль «Космические ветры» (выставки фоторабот, плакатов, картин на тему «Космос моими глазами», «Гагарин - наш герой», запуск воздушных змеев и шаров). По приглашению администрации Краснодарского края на торжества приехали В. В. Горбатко, А. Н. Березовой и С.Е.Трещев. Они участвовали в юбилейных мероприятиях, встречались с членами КРОО «Федерация космонавтики Кубани» и ветеранами ракетнокосмической отрасли.

Очередной всплеск коммеморативной активности в Краснодарском крае имел место в связи с празднованием 60-летия полета Ю.А.Гагарина [29]. В крае проведено более 3000 праздничных мероприятий. Крупнейшими офлайн- и онлайн-проектами стали акции «Космос своими руками», «Космический маршрут», «Я живу на улице Гагарина», «Космическая поэзия», флешмобы «Наука - это космос», «Космическое ГТО», «Космический пульс России», «Первые в космосе», встречи с ветеранами отрасли, лекции, кинопоказы и т.д. В музеях состоялось 110 выставок, которые посетили более 7000 человек, заложено 19 «космических» аллей [10].

Тема космоса - знаковая в произведениях кубанских поэтов В. Б. Бакалдина, И. Ф.Вараввы, К.А. Обойщикова, В.С. Подкопаева, Т. И. Литовченко, С. А. Медведевой, О. И. Давыденко, В. Г. Саакова, композитора В. Д. Пономарева и др. [15, с. 252-257] [34]. 
ный фильм «Космические тропы Кубани» [16] был создан по инициативе КРОО «Федерация космонавтики Кубани». Большое количество медиа-материалов сопровождало на Кубани празднование 60-летия полета Ю.А. Гагарина (интервьюс членами КРОО «Федерация космонавтики Кубани», репортажи об открытии выставок, проведении торжественных мероприятийв Краснодаре,Новороссийске,Сочи) [7][11].

Научное исследование региональных аспектов освоения космоса началось в 1970-е гг. по инициативе Т. И. Агаповой. Эту работу поддержали академик В.П.Глушко [30], общественная организация «Федерация космонавтики СССР» (И.А. Меркулов, И. Г.Борисенко, Е.В.Матысик), научные и научнопроизводственные организации (АН СССР, НПО «Энергия»), крупные музеи космонавтики Москвы, Калуги. При поддержке краевого отделения ВоОПиК с участием московских ученых были проведены конференции «Памятники авиации и космонавтики и их использование в коммунистическом воспитании трудящихся» (1974-1977). Личная поддержка академика В. П. Глушко и передача в дар «космических» экспонатов послужили началом создания школьного музея авиации и космонавтики в школе № 72 в Краснодаре [25, с. 38].

В 1987 г. деятельность общественного движения «Кубань и космонавтика» приобретает поддержку коллективного члена общественной организации «Федерация космонавтики СССР» - Краевого комитета космонавтики, созданного на базе Южно-российского института мониторинга земель и экосистем, который возглавил директор института Э. М. Трахов [16]. В этом же году по приглашению комитета космонавтики край посетил А.Н.Березовой, приняв участие в торжествах к 90-летию Ю.В.Кондратюка в Крыловском районе и заложив камень в основание памятника первому искусственному спутнику Земли в станице Некрасовской Усть-Лабинского района (1988). Продолжилась традиция проведения слетов юных друзей космонавтики, занимавшихся поисковой работой: четвертый слет состоялся в Краснодаре с участием ученых В. А. Лобанова, В. Г. Валовича (1988).

Традиция сотрудничества с московскими учеными была продолжена в постсовет- ский период. Благодаря усилиям членов движения «Кубань и космонавтика» в сотрудничестве с научным сообществом Кубани прошли научные конференции «Кубань и космонавтика» к 40-летию космической эры (1998) [19], «Кубанцы - защитники Отечества» памяти Г. Я.Бахчиванджи (1999), «Научное наследие советской эпохи: современное осмысление» к 100-летию со дня рождения Н. Г. Чернышева (2006) [22], «Кубань и космонавтика» к 50-летию полета Ю. А. Гагарина (2013) [20] «История регионального научного сообщества: проблемы изучения» (2007) [12], «Памятники истории космонавтики и развитие внутреннего туризма» (2019, совместно с Южным филиалом Института Наследия), школьные конференции «Проектная и исследовательская деятельность: актуальные вопросы космонавтики, дисциплин естественно-научного и гуманитарного цикла» $(2020,2021)$.

Одной из форм сохранения памяти об истории освоения космоса выступают научно-исследовательские конкурсы для школьников, преследующие задачи героикопатриотического воспитания и аэрокосмического образования учащихся. История зарождения малых «Гагаринских чтений» на Кубани связана спразднованием 30-летия полета Ю.А.Гагарина под эгидой краевого комитета космонавтики и малой академии наук учащихся Кубани (1991). В 2000-е гг. их организатором выступали краевые органы образования и науки, аплощадкой становились краевой дворец пионеров и школьников, музей авиации и космонавтики гимназии № 72, дворец детского творчества в Краснодаре. В 2010 г. в «Гагаринских чтениях» приняли участие 78 учащихся из 35 районов края [2], в 2014-300 школьников [18]. В последние несколько лет краевые «чтения» не проводятся, однако продолжаются традиции проведения конкурсов исследовательских работ в отдельных школах и городах края.

На страницах региональных печатных изданий находили отражение все знаковые события в истории космонавтики, юбилейные мероприятия. Так, 60-летию полета Ю. А. Гагарина были посвящены номера краевых печатных изданий Краснодарского края «Кубанские 
новости», «Вольная Кубань», «Кубань сегодня», «Аргументы и факты. Кубань», «Российская газета. Кубань. Северный Кавказ», многих районных и городских газет.

Вопросам космического наследия посвящены спецвыпуски журнала Краснодарского научного центра Адыгской (Черкесской) Международной академии наук $(1998,2000)$. Позже практики деятельности региональных центров космонавтики публикуются в научнопопулярном журнале КРОО «Федерация космонавтики Кубани» $(2006,2011,2017)$.

В 2000-е гг. в крае вышел ряд биографических изданий, посвященных кубанским ученым, космонавтам, общественным деятелям: Н. Г. Чернышеву [3], В. В. Горбатко [9], Т. И. Агаповой [25]. К 50-летию полета Ю.А. Гагарина издана брошюра «Их к звездам мужество зовет» [13].

Развитие интернет-коммуникаций привело к формированию в начале XXI в. тематических сайтов, виртуальных музеев космонавтики, официальных страниц в сети Интернет и социальных сетях. Примером могут служить официальный интернет-сайт (www. museum-cosmos.ru) и страница в социальной сети (Instagram@arhipkacosmos) музея космонавтики в поселке Архипо-Осиповка, дающие представление о музейных событиях и экспонатах. На веб-странице мемориального музея Ю. В. Кондратюка (www.музейкондратюка.pф) посетители могут совершить виртуальную экскурсию, познакомиться с историей музея, его экспонатами. Среди коммуникативных площадок в социальных медиа можно отметить официальную страницу в сети Instagram КРОО «Федерация космонавтики Кубани» (@ kubankosmos).

Заключение. Традиции целенаправленного сохранения исторической памяти о достижениях отечественной космонавтики, как в общесоюзном, так и в региональных масштабах, начали формироваться практически одновременно с началом космической эры. Трансляция наследия космонавтики происходила в результате взаимодействия общественных организаций, властных структур, музейных и образовательных учреждений, представителей научной и художественной интеллигенции.
В 1960-1990-е гг. формируются мемориальные пространства для увековечивания кубанцев, внесших весомый вклад в освоение космоса - Г. Я. Бахчиванджи, Ю. В. Кондратюка; В. В. Горбатко, В.И. Севастьянова, А. Н. Березового, Н.Г. Чернышева. Их подвиг визуализируется в многочисленных монументах, природных объектах (мемориальные деревья, аллеи), их именами называются улицы, образовательные и иные учреждения.

Специализированными институтами трансляции знаний об истории и деятелях космоса выступают музеи космонавтики, в том числе школьные, а также планетарии, обсерватории, выставочные центры.

Основным актором коммеморации, начиная с 1971 г., является краевое общественное движение «Кубань и космонавтика» под руководством Т.И. Агаповой, действовавшее в тесном контакте с Советом ВООПИК, крайкомом ВЛКСм, вузами, школами, музеями, дворцами и домами пионеров. В 1980-е гг. официальным органом движения стал Краевой комитет космонавтики во главе с Э. М. Траховым. Сегодня эстафету «Кубани и космонавтики» приняла КРОО «Федерация космонавтики Кубани».

Характерной чертой последних десятилетий стало повышение интереса общества к теме космоса и появление интернет-практик мемориализации исторических событий космонавтики на Кубани: в крае открыты новые музеи, памятники, проводятся конференции, издаются книги, журналы, организуются тематические выставки.

Деятельность, нацеленная на сохранение исторической и культурной памяти о событиях и деятелях космонавтики на Кубани, является важной частью патриотического воспитания, формирования чувства гордости за отечественные научно-технические достижения, укоренении в сознании населения представлений о вкладе кубанцев в освоение космоса.

Данное исследование может быть продолжено с позиций компаративного подхода, с точки зрения сравнения формирования «мест памяти» и опыта популяризации наследия космонавтики в различных регионах страны, разработки тематических экскурсий. 
Vladimir A. SADYM

Cand. Sci. (Museology, Conservation and Restoration

of Historical and Cultural Objects),

Vice-President, Krasnodar Regional Public Organization

Kuban Cosmonautics Federation,

Krasnodar, Russian Federation,

sadymvlad@mail.ru

ORCID: 0000-0002-2340-2585

Karine B. SADYM

Cand. Sci. (National History), Assoc. Prof., Kuban State Medical University,

Krasnodar, Russian Federation,

karinakor@mail.ru

ORCID: 0000-0002-9892-4257

\title{
Historical and Cultural Heritage of Cosmonautics in Kuban: "Places of Memory" and Commemorative Practices
}

\begin{abstract}
The article analyzes the practices of preserving and transmitting the historical and cultural heritage of cosmonautics in Krasnodar Krai in the period from the 1960s to the present, and determines the significance of these activities in the formation of cultural memory. Kuban has a rich "space" heritage: scientists, test pilots, and cosmonauts lived and worked here, and dozens of Soviet and Russian cosmonauts, including Yuri Gagarin, visited the region in different years. The main sources of the research were documents of the regional public movement Kuban and Cosmonautics, and the Krasnodar Regional Public Organization Kuban Cosmonautics Federation; materials of museums, periodicals, Internet sites, publications that captured the memory of space exploration, monuments and memorable places, toponymic data, works of fine art. Among the research methods are comparative-historical, typological, retrospective, as well as the method of included observation, due to the long-term activity of one of the authors in Kuban Cosmonautics Federation. New facts about the Kuban cosmonauts and scientists of the space industry are presented. The authors classify "places of memory". The memorial complexes of cosmonautics in Kuban villages (to Yu.V. Kondratyuk in Oktyabrskaya, to N.G. Chernyshev in Kazan, to G.Ya. Bakhchivandzhi in Brinkovskaya); monuments and busts, commemorative plaques to the figures of cosmonautics (Yu.A. Gagarin, D.I. Kozlov, V.V. Gorbatko, V.I. Sevastyanov, N.G. Chernyshev); museums, including specialized ones (the Museum of Cosmonautics in village Arkhipo-Osipovka, the memorial museum of Yu.V. Kondratyuk, and others); planetariums and observatories; natural objects (memorial trees, alleys). The article describes the activities of Kuban's public organizations created for the popularization of the legacy of cosmonautics. The influence of space exploration on regional toponyms and names of institutions is noted. The main actors, stages, content and trends in the development of "space" commemoration, its all-Union (all-Russian) and regional components, the continuity of Soviet and modern approaches are considered. The authors conclude the "space" heritage is transmitted through the interaction of public organizations, government agencies, museum and educational institutions, representatives of scientific and artistic intelligentsia. The popularization of the space heritage is essential for patriotic education, for the formation in society of a sense of pride of Russian scientific and technological achievements, and for the dissemination of knowledge about the contribution of the natives of Kuban to space exploration.
\end{abstract}

Keywords: cosmonautics, historical and cultural heritage, Krasnodar Krai, commemoration, "places of memory", monuments, commemorative practices. 


\section{Использованная литература:}

1.Беседина Е. А., Буркова Т. В. «Город должен говорить...»: мемориальная доска как знак коммеморации и коммуникации в социокультурном пространстве // Люди и тексты. Исторический альманах. 2014. №6. С. 150-174.

2.В Краснодаре начались «Гагаринские чтения» [Электронный ресурс] // Информационный портал «Кубань 24». URL: https://kuban24.tv/item/vkrasnodare-nachalis-gagarinskie-chteniya (дата обращения: 20.04.2021).

3.Вознесший славу Кубани до лунных высот (К 100-летию со дня рождения Н. Г. Чернышева). Краснодар: Диапазон-В, 2006.

4.Выставка «Планета Земля». Фотоработы летчиков космонавтов [Электронный ресурс] // KUDAGO. URL: https://kudago.com/sochi/event/vystavka-planeta-zemlya/ (дата обращения: 15.02.2021).

5. Горлова И. И., Костина Н. А. Современное краеведческое движение в лицах: Энвер Махмудович Трахов [Электронный ресурс] // Наследие веков. 2017. № 4. C. 84-92. URL: http://old.heritage-magazine.com//wpcontent/uploads/2017/12/2017_4_Gorlova_Kostina.pdf (дата обращения 03.04.2021).

6.Горлова И. И., Литовченко Т. И., Садым В. А. Профессор Т. И. Агапова: жизнь и деятельность // История регионального научного сообщества: проблемы изучения / Отв. ред. А. Н. Еремеева. Краснодар: Кубанькино, 2007. С. $15-30$.

7.День космонавтики: 60 лет в космосе [Электронный ресурс] // Youtube. URL: https://www.youtube. com/watch?v=58c6V0QXZyQ\&t=476s (дата обращения: 24.03.2021).

8. Еремеева А. Н. Научная жизнь и научное сообщество Кубани в XX веке. Краснодар: Кубанькино, 2006.

9.Звездный сын Кубани: к 70-летию дважды Героя Советского Союза, летчика-космонавта СССР генерал-майора авиации В. В. Горбатко. / ред.-сост. В. И. Ильин. Краснодар: Периодика Кубани, 2004.

10. Информационная справка о реализации на территории Краснодарского края мероприятий, приуроченных ко Дню космонавтики. Рукопись // Архив Краснодарской региональной общественной организации «Федерация космонавтики Кубани.

11. История, о которой молчали 40 лет: как Краснодарский край связан с первым полетом человека в космос [Электронный ресурс] // Youtube. URL: https:// www.youtube.com/watch?v=JCCFqvX8W8U (дата обращения: 30.04.2021).

12. История регионального научного сообщества: проблемы изучения: материалы научной конференции / Отв. ред. А. Н. Еремеева. Краснодар: Кубанькино, 2007.

13. Их к звездам мужество зовет! О кубанских ученых-первопроходцах освоения космического пространства и летчиках-космонавтах / Ред. совет: Э. М. Трахов и др. Краснодар: Диапазон-В, 2011.

14. Какой регион в России больше всего связан с космонавтикой [Электронный ресурс] // T-Ж. URL: https://journal.tinkoff.ru/stat-space/ (дата обращения: 30.04.2021).

15. Книга Памяти. Устремленные в небо / Ред.сост. М. П. Морева. Т. 19. Краснодар: Краснодарские известия, 1997.

\section{References:}

1. Besedina, E.A. \& Burkova, T.V. (2014) "The City Should Speak...": Memorial Plaque as a Sign of Commemoration and Communication in Sociocultural Space. Lyudi i teksty. Istoricheskiy al'manakh. 6. pp. 150-174. (In Russian).

2. Kuban' 24. (2010) V Krasnodare nachalis' "Gagarinskie chteniya" [Gagarin Readings Began in Krasnodar]. [Online] Available from: https://kuban24.tv/ item/v-krasnodare-nachalis-gagarinskie-chteniya (Accessed: 20.04.2021).

3. Diapazon-V. (2006) Voznesshiy slavu Kubani do lunnykh vysot (K 100-letiyu so dnya rozhdeniya N. G. Chernysheva) [He Raised the Glory of Kuban High to the Moon (To the 100th Anniversary of the Birth of NG Chernyshev)]. Krasnodar: Diapazon-V.

4. KUDAGO. (2015) Vystavka "Planeta Zemlya". Fotoraboty letchikov kosmonavtov [Exhibition "Planet Earth". Photographs of Pilot-Cosmonauts]. [Online] Available from: https://kudago.com/sochi/event/vystavka-planeta-zemlya/ (Accessed: 15.02.2021).

5. Gorlova, I.I. \& Kostina, N.A. (2017) Modern Local History Movement through the Personalities: Enver Makhmudovich Trakhov. Nasledie vekov - Heritage of Centuries. 4. pp. 84-92. [Online] Available from: http://old.heritage-magazine.com//wp-content/uploads/2017/12/2017_4_Gorlova_Kostina.pdf (Accessed: 03.04.2021). (In Russian).

6. Gorlova, I.I., Litovchenko, T.I. \& Sadym, V.A. (2007) Professor T.I. Agapova: zhizn' i deyatel'nost' [Professor T.I. Agapova: Life and Work]. In: Eremeeva, A.N. (ed.) Istoriya regional'nogo nauchnogo soobshchestva: problemy izucheniya [History of the Regional Scientific Community: Problems of Study]. Krasnodar: Kuban'kino. pp. 15-30.

7. YouTube. (2021) Den' kosmonavtiki: 60 let $v$ kosmose [Cosmonautics Day: 60 Years in Space]. [Video]. [Online] Available from: https://www.youtube.com/ watch? $=58 c 6 V 0 Q X Z y Q \& \mathrm{t}=476 \mathrm{~s}$ (Accessed: 24.03 .2021 ).

8. Eremeeva, A.N. (2006) Nauchnaya zhizn' i nauchnoe soobshchestvo Kubani $v$ XX veke [Scientific Life and Scientific Community of Kuban in the 20th Century]. Krasnodar: Kuban'kino.

9. Il'in, V.I. (ed.) (2004) Zvezdnyy syn Kubani: $k$ 70-letiyu dvazhdy Geroya Sovetskogo Soyuza, letchika-kosmonavta SSSR general-mayora aviatsii V. V. Gorbatko [The Famous Son of Kuban: To the 70th Anniversary of V.V. Gorbatko, Twice Hero of the Soviet Union, Pilot-Cosmonaut of the USSR, Major General of Aviation]. Krasnodar: Periodika Kubani.

10. Archive of the Krasnodar Regional Public Organization Kuban Cosmonautics Federation. Informatsionnaya spravka o realizatsii na territorii Krasnodarskogo kraya meropriyatiy, priurochennykh ko Dnyu kosmonavtiki [Information Note on the Implementation in the Territory of Krasnodar Krai of Events Timed to the Day of Cosmonautics]. Manuscript.

11. YouTube. (2021) Istoriya, o kotoroy molchali 40 let: kak Krasnodarskiy kray svyazan s pervym poletom cheloveka $v$ kosmos [Story That Was Silenced for 40 Years: How Krasnodar Krai Is Connected with the First Manned Flight into Space]. [Video]. [Online] Available from: https:// www.youtube.com/watch?v=JCCFqvX8W8U (Accessed: 30.04.2021).

12. Eremeeva, A.N. (ed.) (2007) Istoriya regional'nogo nauchnogo soobshchestva: problemy izucheniya [History of 
16. Космические тропы Кубани. Документальный фильм [Электронный ресурс] // Youtube. URL: https:// www.youtube.com/watch?v=8BC1MULiFM4 (дата обращения: 19.03.2021).

17. Кубанские космонавты в числе первых побывали на орбите [Электронный ресурс] // Youtube. URL: https://www.youtube.com/watch?v=94Y3gZUD1Hk (дата обращения: 05.04.2021).

18. Кубанские школьники собрались на финал краевого конкурса «Гагаринские чтения» [Электронный ресурс] // Информационный портал «Кубань 24». URL: https://kuban24.tv/item/kubanskie-shkolniki-sobralis-nafinal-kraevogo-konkursa-gagarinskie-chteniya (дата обращения: 02.02.2021).

19. Кубань и космонавтика: Материалы региональной науч.-практ. конф. / Науч. ред. Т. И. Агапова. Краснодар: б.и., 1998.

20. Кубань и космонавтика. Материалы науч.-практ. конф., посвященной 50-летию полета Ю. А. Гагарина / Отв. ред. Э. М. Трахов. Краснодар: б.и., 2013.

21. Лариса Князева, заведующая научно-экспозиционным отделом музея истории города-курорта Сочи [Электронный ресурс] // Youtube. URL: https://www. youtube.com/watch?v=qj95xu3BQSo (дата обращения: 10.01.2021).

22. Научное наследие советской эпохи: современное осмысление. Материалы науч.-практ. конф., посвящ. 100-летию со дня рождения Николая Гавриловича Чернышева (Краснодар, 8 сент., 2006 г.) / Отв. ред. А. Н. Еремеева. Краснодар: Кубанькино, 2006.

23. Нора П. Между памятью и историей. Проблематика мест памяти // Франция-память. СПб: Изд-во Санкт-Петерб. ун-та, 1999. С. 17-50.

24. Открытие бюста Юрию Алексеевичу Гагарину в Краснодарском высшем военном авиационном училище летчиков имени Героя Советского Союза А. К. Серова [Электронный ресурс] // Краснодарское высшее военное авиационное училище летчиков. URL: https:// kvvaul.ru/activity/detail.php?ID=29712 (дата обращения: 03.05.2021).

25. Пламенный пропагандист космонавтики. 0 жизни и деятельности основателя и первого руководителя общественного движения «Кубань и космонавтика» Т. И. Агаповой / Под ред. В. А. Садыма. Краснодар: Диапазон-В, 2011.

26. Постановление ЗС Краснодарского края от 12.12.2007 N 38-П «0 внесении изменений в Постановление Законодательного Собрания Краснодарского края «Об утверждении краевой целевой программы «70-летие образования Краснодарского края и 215-летие освоения казаками кубанских земель» на 2006-2007 годы». Раздел «Кубань и космонавтика» [Электронный ресурс] // Гарант.ру: информационно-правовой портал. URL: https:// base.garant.ru/23974505/ (дата обращения: 03.04.2021).

27. Президент Федерации космонавтики Кубани Энвер Трахов: для меня космос стал профессией [Электронный ресурс] // Youtube. URL: https://www. youtube.com/watch?v=jEQyJFLpWXY (дата обращения: 05.02.2021).

28. Программа «Дни Ю. А. Гагарина» (1 апреля 15 мая 1991 г.), посвященные 30-летию первого полета человека в космос и 20-летию общественного the Regional Scientific Community: Problems of Study]. Conference Proceedings. Krasnodar: Kuban'kino.

13. Trakhov, E.M. et al. (2011) Ikh $k$ zvezdam muzhestvo zovet! O kubanskikh uchenykh-pervoprokhodtsakh osvoeniya kosmicheskogo prostranstva i letchikakh-kosmonavtakh [Courage Calls Them to the Stars! About Kuban Scientists Pioneers of Space Exploration and Pilot-Cosmonauts]. Krasnodar: Diapazon-V.

14. T-Zh. (2021) Kakoy region $v$ Rossii bol'she vsego svyazan s kosmonavtikoy [Which Region in Russia Is Most Associated with Cosmonautics]. [Online] Available from: https://journal.tinkoff.ru/stat-space/ (Accessed: 30.04.2021).

15. Moreva, M.P. (ed.) (1997) Kniga Pamyati. Ustremlennye $v$ nebo [Book of Memory. Striving to the Sky]. Vol. 19. Krasnodar: Krasnodarskie izvestiya.

16. YouTube. (2021) Kosmicheskie tropy Kubani. Dokumental'nyy fil'm [Space Trails of Kuban. A Documentary]. [Video]. [Online] Available from: https://www.youtube.com/ watch?v=8BC1MULiFM4 (Accessed: 19.03.2021).

17. YouTube. (2021) Kubanskie kosmonavty v chisle pervykh pobyvali na orbite [Kuban Cosmonauts Were among the First to Be in Orbit]. [Online] Available from: https:// www.youtube.com/watch?v=94Y3gZUD1Hk (Accessed: 05.04.2021).

18. Kuban' 24. (2011) Kubanskie shkol'niki sobralis' na final kraevogo konkursa "Gagarinskie chteniya" [Kuban Schoolchildren Gathered for the Final of the Gagarin Readings Regional Competition]. [Online] Available from: https:// kuban24.tv/item/kubanskie-sh kolniki-sobralis-na-final-kraevogo-konkursa-gagarinskie-chteniya (Accessed: 02.02.2021).

19. Agapova, T.I. (ed.) (1998) Kuban' i kosmonavtika [Kuban and Cosmonautics]. Conference Proceedings. Vol. 1. Krasnodar: [s.n.].

20. Trakhov, E.M. (ed.) (2013) Kuban' i kosmonavtika [Kuban and Cosmonautics]. Conference Proceedings. Krasnodar: [s.n.].

21. YouTube. (2021) Larisa Knyazeva, zaveduyushchaya nauchno-ekspozitsionnym otdelom muzeya istorii goroda-kurorta Sochi [Larisa Knyazeva, Head of the Scientific and Exposition Department of the Museum of the History of the Resort City of Sochi]. [Video]. [Online] Available from: https://www.youtube.com/watch?v=qj95xu3BQSo (Accessed: 10.01.2021).

22. Eremeeva, A.N. (ed.) (2006) Nauchnoe nasledie sovetskoy epokhi: sovremennoe osmyslenie [Scientific Heritage of the Soviet Era: A Modern Understanding]. Conference Proceedings. Krasnodar. 8 September 2006. Krasnodar: Kuban'kino.

23. Nora, P. (1999) Mezhdu pamyat'yu i istoriey. Problematika mest pamyati [Between Memory and History. The Problem of Places of Memory]. In: Nora, P. et al. Frantsiyapamyat' [Realms of Memory: Rethinking the French Past]. St. Petersburg: St. Petersburg State University. pp. 17-50.

24. Krasnodar Higher Military Aviation School. (2021) Otkrytie byusta Yuriyu Alekseevichu Gagarinu v Krasnodarskom vysshem voennom aviatsionnom uchilishche letchikov imeni Geroya Sovetskogo Soyuza A. K. Sero$v a$ [Opening of the Bust of Yuri Gagarin at Krasnodar Higher Military Aviation School Named after Hero of the Soviet Union A.K. Serov]. [Online] Available from: 
движения «Кубань и космонавтика». Краснодар, 1991 // Архив Краснодарской региональной общественной организации «Федерация космонавтики Кубани».

29. Распоряжение Правительства Российской Федерации от 22.05.2019 г. № 1010-р [Электронный ресурс] // Правительство Российской Федерации. URL: http://government.ru/docs/all/121972/ (дата обращения: 24.02.2021).

30. Садым В. А., Литовченко Т. И. Академик В. П. Глушко и космический дискурс на Кубани // История научной интеллигенции Юга России: межрегиональные и международные аспекты : материалы научной конференции / Отв. ред. А. Н. Еремеева. Краснодар: Кубанькино, 2008. С. 146-154.

31. Садым В. А. Он видел Кубань из космоса // Судьба и Родина едины. Сборник очерков о выдающихся кубанцах - юбилярах 2007 года. Краснодар: Диапазон-В, 2007. С. 17-25.

32. Садым В. А. Садым К. Б. Общественное движение «Кубань и космонавтика» как феномен социокультурной жизни Кубани второй половины XX века // Покорение космоса: история и современность: материалы межвузовской научной конференции с международным участием, посвященной 60-летию полета Ю. А. Гагарина в космос. Москва: Рос. экон. ун-т им. Г. В. Плеханова, 2021. C. 97-103.

33. Садым В. А., Садым К. Б. Школьные музеи космонавтики на Кубани как центры краеведческой деятельности [Электронный ресурс] // Наследие веков. 2018. № 1. C. 44-55. URL: http://heritage-magazine.com/ wpcontent/uploads/2018/02/2018_1_Sadym_Sadym.pdf (дата обращения: 20.04.2021).

34. Творческий альманах членов клуба «Прикубаночка». Краснодар: б/и, 2017.

35. Шуб М. Л. Феномен коммеморации: опыт культурологического анализа практик публичного поминовения (на примере наименования улиц Челябинска) // Обсерватория культуры. 2018. Т. 15. № 2. С. 161-169.

36. Eremeeva A. Constructing Cosmic Enthusiasm: A Case Study of the Krasnodar Territory // Soviet Space Culture. Cosmic Enthusiasm in Socialist Societies / Ed. by Eva Maurer, Julia Richers, Monica Rüthers and Carmen Scheide. N. Y.: Palgrave Macmillan, 2011. P. 139-150.

37. Sadym V. Propaganda of the historical and cultural heritage of cosmonautics: The experience of Russian regional non-governmental organizations // Soviet Space Culture. Cosmic Enthusiasm in Socialist Societies / Ed. by Eva Maurer, Julia Richers, Monica Rüthers and Carmen Scheide. N. Y.: Palgrave Macmillan, 2011. P. 151-163.
https://kvvaul.ru/activity/detail.php?ID=29712 (Accessed: 03.05.2021).

25. Sadym, V.A. (ed.) Plamennyy propagandist kosmonavtiki. O zhizni i deyatel'nosti osnovatelya i pervogo rukovoditelya obshchestvennogo dvizheniya "Kuban' i kosmonavtika" T. I. Agapovoy [An Ardent Propagandist of Cosmonautics. On the Life and Work of T.I. Agapova, the Founder and First Head of the Public Movement "Kuban and Cosmonautics"]. Krasnodar: Diapazon-V.

26. Garant.ru. (2007) Resolution of the Legislative Assembly of Krasnodar Krai of 12.12.2007 No. 38-P: On Amendments to the Resolution of the Legislative Assembly of Krasnodar Krai "On Approval of the Regional Target Program '70th Anniversary of the Formation of Krasnodar Krai and the 215th Anniversary of the Cossack's Development of Kuban' for 20062007". Section "Kuban and Cosmonautics". [Online] Available from: https://base.garant.ru/23974505/ (Accessed: 03.04.2021). (In Russian).

27. YouTube. (2017) Prezident Federatsii kosmonavtiki Kubani Enver Trakhov: dlya menya kosmos stal professiey [President of the Kuban Cosmonautics Federation Enver Trakhov: For Me Space Has Become a Profession]. [Video]. [Online] Available from: https://www.youtube.com/watch?v=jEQyJFLpWXY (Accessed: 05.02.2021).

28. Archive of the Krasnodar Regional Public Organization Kuban Cosmonautics Federation. (1991) Programma "Dni Yu. A. Gagarina" (1 aprelya - 15 maya 1991 g.), posvyashchennye 30-letiyu pervogo poleta cheloveka v kosmos i 20-letiyu obshchestvennogo dvizheniya "Kuban' i kosmonavtika" [The Program "Days of Yuri Gagarin" (April 1 - May 15, 1991), Dedicated to the 30th Anniversary of the First Manned Flight into Space and the 20th Anniversary of the Public Movement "Kuban and Cosmonautics"]. Krasnodar.

29. Government of the Russian Federation. (2019) Rasporyazhenie Pravitel'stva Rossiyskoy Federatsii ot 22.05.2019 g. № 1010-r [Order of the Government of the Russian Federation of May 22, 2019, No. 1010-R]. [Online] Available from: http://government.ru/docs/all/121972/ (Accessed: 24.02.2021).

30. Sadym, V.A. \& Litovchenko. T.I. (2008) [Academician V.P. Glushko and Space Discourse in Kuban]. Istoriya nauchnoy intelligentsii Yuga Rossii [History of the Scientific Intelligentsia of the South of Russia: Interregional and International Aspects]. Conference Proceedings. Krasnodar: Kuban'kino. pp. 146-154. (In Russian).

31. Sadym, V.A. (2007) On videl Kuban' iz kosmosa [He Saw Kuban from Outer Space]. In: Sud'ba i Rodina ediny. Sbornik ocherkov o vydayushchikhsya kubantsakh - yubilyarakh 2007 goda [Fate and Homeland Are One. A Collection of Essays about Outstanding Kuban Citizens Celebrating Anniversaries in 2007]. Krasnodar: Diapazon-V. pp. 17-25.

32. Sadym, V.A. \& Sadym, K.B. (2021) [Public Movement "Kuban and Cosmonautics" as a Phenomenon of the Sociocultural Life of Kuban in the Second Half of the 20th Century]. Pokorenie kosmosa: istoriya i sovremennost' [Space Conquest: History and Modernity]. Conference Proceedings. Moscow: Plekhanov Russian University of Economics. pp. 97-103. (In Russian).

33. Sadym, V.A. \& Sadym, K.B. (2018) School Museums of Cosmonautics in the Kuban Region as Centres of Regional Studies Activities. Nasledie vekov - Heritage of Centuries. 1. pp. 44-55. [Online] Available from: http://heritage-mag- 
azine.com/wpcontent/uploads/2018/02/2018_1_Sadym_ Sadym.pdf (Accessed: 20.04.2021). (In Russian).

34. Anon. (2017) Tvorcheskiy al'manakh chlenov kluba "Prikubanochka" [Creative Almanac of Members of the "Prikubanochka" Club]. Krasnodar: [s.n.].

35. Shub, M.L. (2018) Commemoration Phenomenon: An Experience of Culturological Analysis of Public Commemoration Practices (by the Example of Chelyabinsk Streets Naming). Observatoriya kul'tury - Observatory of Culture. 15 (2). pp. 161-169. (In Russian). DOI: 10.25281/2072-3156-2018-15-2-161-169

36. Eremeeva, A. (2011) Constructing Cosmic Enthusiasm: A Case Study of the Krasnodar Territory. In: Maurer, E. et al. (eds) Soviet Space Culture. Cosmic Enthusiasm in Socialist Societies. N. Y.: Palgrave Macmillan. pp. 139-150.

37. Sadym, V. (2011) Propaganda of the historical and cultural heritage of cosmonautics: The experience of Russian regional non-governmental organizations. In: Maurer, E. et al. (eds) Soviet Space Culture. Cosmic Enthusiasm in Socialist Societies. N. Y.: Palgrave Macmillan. pp. 151-163.

Полная библиографическая ссылка на статью:

Садым, В. А. Историко-культурное наследие космонавтики на Кубани: «места памяти» и коммеморативные практики / В. А. Садым, К. Б. Садым // Наследие веков. - 2021. - №2. - С. 35-53. DOI: 10.36343./SB.2021.26.2.003

Full bibliographic reference to the article:

Sadym, V. A., Sadym, K. B. (2021) Historical and Cultural Heritage of Cosmonautics in Kuban: "Places of Memory" and Commemorative Practices. Nasledie vekov - Heritage of Centuries. 2. pp. 35-53. (In Russian). DOI: 10.36343/SB.2021.26.2.003 